\title{
Trace Metal Determinations Using Voltammetric (DPV-HMDE) and Atomic Absorption Spectrometry (F-AAS and ET-AAS) in Bottom Sediment, Cod, Herring, and Cormorant Tissue Samples
}

\author{
Irena Baranowska ${ }^{1 *}$, Bartosz Kowalski ${ }^{1}$, Halina Polkowska-Motrenko ${ }^{2}$, \\ Zbigniew Samczyński² \\ 'Department of Inorganic, Analytical Chemistry and Electrochemistry, Chemical Faculty, \\ Silesian University of Technology, Strzody 7, 44-100 Gliwice, Poland \\ ${ }^{2}$ Institute of Nuclear Chemistry and Technology, Laboratory of Nuclear Analytical Techniques, \\ Dorodna 16, 03-195 Warsaw, Poland
}

Received: February 9, 2015

Accepted: March 15, 2015

\begin{abstract}
We developed a voltammetric method using hanging mercury drop electrode (HMDE) for the determination of copper, zinc, lead, and cadmium, and an atomic absorption spectrometry method with flame and electrothermical atomisation for the determination of cobalt, copper, cadmium, lead, zinc, ferrum, manganese, and nickel. These methods were applied for the determination of elements in bottom sediment and animal tissue samples - candidates for certificate reference materials. The mineralisation procedure using a closed microwave-assisted system, which allowed for total decomposition of samples, was applied. For accurate testing of developed methods for elemental determination, Buffalo River sediment (NIST) and fish muscle (ERM) certified reference materials were used. Limits of detection (LOD) and limits of quantification (LOQ) varied depending on technique used. For F-AAS, LOD values were between $2.2-12 \mathrm{mg} \cdot \mathrm{kg}^{-1}$, for ET-AAS 0.10-0.35 $\mathrm{mg} \cdot \mathrm{kg}^{-1}$, and 0.014-0.021 mg $\cdot \mathrm{kg}^{-1}$ for HMDE. LOQ values varied between $6.5-30 \mathrm{mg} \cdot \mathrm{kg}^{-1}, 0.31-1.1 \mathrm{mg} \cdot \mathrm{kg}^{-1}$, and $0.042-0.063 \mathrm{mg} \cdot \mathrm{kg}^{-1}$, for F-AAS, ET-AAS, and HMDE, respectively. Linearity ranges also varied for each technique: $0.005-1.0 \mathrm{mg} \cdot \mathrm{kg}^{-1}$ for HMDE, $0.35-50 \mathrm{mg} \cdot \mathrm{kg}^{-1}$ for ET-AAS, and $6.5-500 \mathrm{mg} \cdot \mathrm{kg}^{-1}$ for F-AAS technique. Homogeneity within and between bottles was calculated for each element. Variances did not differ in a statistically significant way, which is why materials can be considered homogenous.
\end{abstract}

Keywords: metal determination, bottom sediment, animal tissues, DPV-HMDE, F-AAS, ET-AAS

\section{Introduction}

Two years ago a consortium consisting of several Polish universities (including the Silesian University of Technology

*e-mail: irena.baranowska@polsl.pl and Institute of Nuclear Chemistry and Technology) were established. The goal of this consortium was to implement a project called MODAS (production and attestation of new types of reference materials crucial for achieving European accreditation for Polish industrial laboratories). This project has sought the development and validation of new refer- 
ence materials that are essential for Polish laboratories, which deal with industrial analytics, for European accreditation. Within this project new materials will be producedcandidates for certified reference materials with different matrices. Among these materials are: the soil in which the analytes are stable organic compounds such as $\mathrm{PAH}$ or PCB; bottom sediment, where the analytes are metals, pharmaceuticals, and other residues; and herring, cod, and cormorant tissues, where the analytes are metals and persistent organic compounds. At this stage, the materials are already produced and the certification process is ongoing.

The certified reference materials are of great importance. They allow validation laboratory methods (accuracy), and are necessary when estimating uncertainty of measurement, recovery test, and calibration. Certified reference materials are also needed to check out the skills of a new laboratory or new laboratory analysts.

Production of CRMs is a laborious and time-consuming process. First of all, the selection of the right amount of material is needed. Then homogenization, initial homogeneity, and dosage into suitable containers needs to be carried out. In the next step sterilization should take place, plus homogeneity and stability. The last step is interlaboratory comparison, which is an essential element of the certification process of the material. Within the consortium, each team is responsible for a different part of the preparation of these materials.

In this work we would like to concentrate on studies of the determination of select metals in bottom sediment, and cod, cormorant, and herring tissues using voltammetric (DPV-HMDE) and spectroscopic methods (F-AAS and ET-AAS). The literature still shows research that focuses on determination of different elements in bottom sediments. Some of the research has concentrated on distribution, mobility, or fractionation of some elements in bottom sediments [1-5]. However, most of the publications describe multi-elemental monitoring studies. The most commonly used technique has been ICP with different detectors: MS [1, 2, 6-8], AES [3, 9, 10], and OES [11]. Moreover, XRF techniques with different modification were also used, as these methods can be applied directly with solid samples [5, 12-15]. One publication described the INAA method for determining elements in bottom sediment [16], and five used the AAS method [4, 14, 17-19]. To our knowledge, there have been only two publications in recent years that have applied electrochemical methods for element determination in bottom sediments $[20,21]$. There is also one publication that compared results from different techniques: F-AAS, ET-AAS, and XRF [16].

Furthermore, research that focuses on determination of elements in animal tissues were also conducted. There are only a few articles that describe determination of metals in the same tissues as described in this work. Two publications we found described elemental determination in cod $[22,23]$, herring [23, 24], and cormorant [25, 26] tissues. However, there are still works that described the determination of trace elements in other tissues. The most popular are fish tissues from lakes and seas all over the world [27-33]. Nevertheless, a few applications were applied to determine elements in other organism tissues from water $[34,35]$ and land [36].

The methods proposed were not hitherto applied for preparation of certified reference materials for bottom sediments, cod, cormorant, and herring tissue samples.

\section{Experimental Procedures}

\section{Reagents and Reference Solutions}

Nitric acid $\left(\mathrm{HNO}_{3}\right)$, hydrochloric acid $(\mathrm{HCl})$, sulphuric acid $\left(\mathrm{H}_{2} \mathrm{SO}_{4}\right)$, and hydrogen peroxide $\left(\mathrm{H}_{2} \mathrm{O}_{2}\right)$ were all suprapure grade (NORMATOM TRACE A, VWR, UK). Hydrofluoric acid (HF) was bought from Merck (SUPRAPUR, Germany) and boric acid was bought from ACROS ORGANICS (EXTRA PURE, USA).

Aqueous stock solutions of $\mathrm{Cd}(\mathrm{II}), \mathrm{Co}(\mathrm{II}), \mathrm{Cu}(\mathrm{II})$, $\mathrm{Fe}(\mathrm{III}), \mathrm{Mn}(\mathrm{II}), \mathrm{Ni}(\mathrm{II}), \mathrm{Pb}(\mathrm{II})$, and $\mathrm{Zn}(\mathrm{II})$ were prepared by dilution of the respective standards $1000 \mathrm{mg} \cdot \mathrm{l}^{-1}$ (Merck, Germany). All solutions were prepared using doubledistilled water (Millipore).

Certified reference materials: RM-8704 Buffalo River Sediment (NIST, USA) and ERM-BB422 (ERM, Belgium) were used for the accuracy measurements.

\section{Instrumentation}

Determination of metals was carried out using atomic absorption spectrometry on an AAS 30 Carl Zeiss (Jena, Germany), both using flame atomisation (F-AAS) with acethylene-air flame and electrothermical atomisation (ET-AAS). Select metals were determined under the specific wavelengths: Cd $228.8 \mathrm{~nm}, \mathrm{Cu} 324.8 \mathrm{~nm}, \mathrm{Co} 240.7 \mathrm{~nm}$, Fe 248.3 nm, Mn 279.5 nm, Ni 232.0 nm, Pb 283.3 nm, and Zn 213.9 nm. Except for Cd and Co, all metals were determined using F AAS. For determination of $\mathrm{Cd}, \mathrm{Co}, \mathrm{Fe}, \mathrm{Mn}$, $\mathrm{Pb}$, and $\mathrm{Zn}$, the ET-AAS technique was also used. The ash and atomisation temperatures were specific for each element: $\mathrm{Cd}\left(460^{\circ} \mathrm{C}, 1750^{\circ} \mathrm{C}\right), \mathrm{Co}\left(800^{\circ} \mathrm{C}, 2300^{\circ} \mathrm{C}\right)$, $\mathrm{Fe}\left(1000^{\circ} \mathrm{C}, 2100^{\circ} \mathrm{C}\right), \mathrm{Mn}\left(1050^{\circ} \mathrm{C}, 1900^{\circ} \mathrm{C}\right), \mathrm{Pb}\left(700^{\circ} \mathrm{C}\right.$, $\left.1900^{\circ} \mathrm{C}\right)$, and $\mathrm{Zn}\left(700^{\circ} \mathrm{C}, 2000^{\circ} \mathrm{C}\right)$. Determining $\mathrm{Cd}, \mathrm{Cu}, \mathrm{Pb}$, and $\mathrm{Zn}$ also was performed using the voltammetric technique of hanging a mercury drop electrode (DPV-HMDE, Eco-Trybo, Czech Republic) with $\mathrm{Ag} / \mathrm{AgCl}$ (in saturated $\mathrm{KCl}$ ) as a reference electrode and a platinum wire as an auxiliary electrode. Before the experiment, solutions were deoxygenated with argon for five minutes, and then after each standard addition were deoxygenated for two minutes. The specific conditions for determination of elements are presented in Table 1. An additional step was added for cod, cormorant, and herring tissues. Because elements in these samples were at lower concentration levels, in order to detect those elements a wait time of $100 \mathrm{~s}$ before analysis was applied to concentrated elements on the mercury drop.

A Multiwave 3000 (Anton Paar GmbH, Germany) was used for mineralisation of samples. This closed microwaveassisted system allowed for rapid sample decomposition at high pressure. 
Table 1. Conditions of determination of $\mathrm{Zn}, \mathrm{Cd}, \mathrm{Pb}$, and $\mathrm{Cu}$ using DPV-HMDE.

\begin{tabular}{|c|c|c|c|c|}
\hline & $\mathrm{Zn}$ & $\mathrm{Cd}$ & $\mathrm{Pb}$ & $\mathrm{Cu}$ \\
\hline Measuring potential & $-921 \mathrm{mV}$ & $-560 \mathrm{mV}$ & $-364 \mathrm{mV}$ & $+59 \mathrm{mV}$ \\
\hline Electrolyte & $\begin{array}{l}0.1 \mathrm{M} \mathrm{HCl} \text { - addition of ammonium } \\
\text { buffer to adjust } \mathrm{pH} \text { to } 4\end{array}$ & \multicolumn{3}{|c|}{$0.1 \mathrm{M} \mathrm{HCl}(\mathrm{pH} 1)$} \\
\hline Starting potential & \multicolumn{4}{|c|}{$-1200 \mathrm{mV}$} \\
\hline Ending potential & \multicolumn{4}{|c|}{$+150 \mathrm{mV}$} \\
\hline Scan rate & \multicolumn{4}{|c|}{$25 \mathrm{mV} / \mathrm{s}$} \\
\hline
\end{tabular}

\section{Sample Preparation}

The bottom sediment was taken from the Vistula River in Torun. After removing gravel and leaves, the collected fresh material was freeze-dried, ground, and sieved through a nylon sieve, and a fraction of particle size below $90 \mu \mathrm{m}$ was separated. The particle size distribution of the collected fraction was tested microscopically and by laser diffraction method. The obtained powdered material was homogenized by mixing in a homogenizer for 16 hours and distributed into bottles made of amber glass. All bottles with the candidate CRM were sterilized by electron beam irradiation with a dose of $28 \mathrm{kGy}$ in order to ensure long-term stability of the material. The same procedure (after liofilisation) was applied for the fish and cormorant tissues.

The $400 \mathrm{mg}$ of bottom sediment and RM-8704 were weighed and mineralised with the mixture comprised of $\mathrm{HNO}_{3}: \mathrm{HCl}: \mathrm{HF}(5: 2: 4, \mathrm{v} / \mathrm{v})$, which allowed for the complete digestion of samples (even the silica). To remove additive hydrofluoric acid, boric acid $\left(\mathrm{H}_{3} \mathrm{BO}_{3}\right)$ was used. The mineralisation samples were then transferred into $50 \mathrm{~mL}$ volummetric flasks. The complete mineralisation programme is presented in Table 2.

The $450 \mathrm{mg}$ of ERM-BB422 and all tissue samples were mineralised. These samples did not contain silica, therefore another mineralisation programme was applied. The best results were achieved where the mineralisation mixture was comprised of $\mathrm{HNO}_{3}: \mathrm{H}_{2} \mathrm{O}_{2}(9: 1.5 ; \mathrm{v} / \mathrm{v})$ (Table 3).

\section{Results}

Different mineralisation programmes were tested to obtain results with good precision and accuracy. These programmes comprised several mixtures of acids $\left(\mathrm{HNO}_{3}, \mathrm{HCl}\right.$, $\mathrm{HF}, \mathrm{H}_{2} \mathrm{SO}_{4}$ ) and $\mathrm{H}_{2} \mathrm{O}_{2}$ in various combinations. The mixtures without $\mathrm{HF}$ acid were unable to decompose silica, which was present in bottom sediment samples. The results for some elements, like $\mathrm{Fe}$ and $\mathrm{Mn}$, were lower than the real values of even $10 \%$, when silica were not digested. Therefore, only mixtures with HF acid can be used for those samples. The results of best accuracy were achieved using the programme presented in Table 2. With tissue samples there were not such problems, because these samples did not contain silica. However, the organic matrix was greater than
Table 2. Mineralisation and complexation programme for bottom sediment samples.

\begin{tabular}{|c|c|c|c|}
\hline Power [W] & Ramp [min] & Hold [min] & Fan \\
\hline 1200 & 15 & 40 & 1 \\
\hline 0 & - & 15 & 3 \\
\hline \multicolumn{4}{|c|}{ Complexation } \\
\hline 1400 & 5 & 15 & 1 \\
\hline 0 & - & 15 & 3 \\
\hline
\end{tabular}

Table 3. Mineralisation programme for tissue samples.

\begin{tabular}{|c|c|c|c|}
\hline Power $[\mathrm{W}]$ & Ramp [min] & Hold [min] & Fan \\
\hline 600 & 10 & 20 & 1 \\
\hline 800 & 5 & 15 & 1 \\
\hline 0 & - & 15 & 3 \\
\hline
\end{tabular}

in bottom sediment, which was a problem when determining elements using the DPV-HMDE method. Therefore, a mineralisation programme (Table 3) that contained $9 \mathrm{ml}$ of $\mathrm{HNO}_{3}$ with the addition of $\mathrm{H}_{2} \mathrm{O}_{2}$ was applied. With this programme organic matter was removed and electrochemical determination could be applied (Fig. 1).

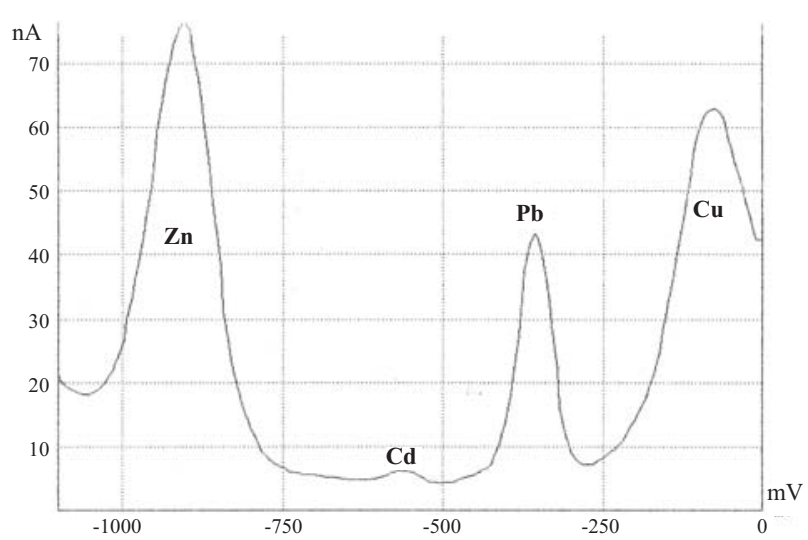

Fig. 1. Voltammogramme of bottom sediment sample (after mineralisation) at $\mathrm{pH} 4$. 
Table 4. Results achieved for the Buffalo River sediment material with uncertainty values.

\begin{tabular}{|c|c|c|c|c|}
\hline \multirow{2}{*}{ Element } & $\begin{array}{l}\text { Certification results from } \\
\text { RM-8704 Report }\end{array}$ & F-AAS & ET-AAS & HMDE \\
\hline & \multicolumn{4}{|c|}{$\left[\mathrm{mg} \cdot \mathrm{kg}^{-1}\right]$} \\
\hline $\mathrm{Cd}$ & $2.94 \pm 0.29$ & - & $2.53 \pm 0.41$ & $2.64 \pm 0.34$ \\
\hline Co & $13.57 \pm 0.43$ & - & $14.29 \pm 1.23$ & - \\
\hline $\mathrm{Fe}$ & $39700 \pm 1000$ & $37592 \pm 3134$ & $38185 \pm 4513$ & - \\
\hline $\mathrm{Mn}$ & $544 \pm 21$ & $537 \pm 14$ & $530 \pm 52$ & - \\
\hline $\mathrm{Ni}$ & $42.9 \pm 3.7$ & $46.1 \pm 5.2$ & - & - \\
\hline $\mathrm{Pb}$ & $150 \pm 17$ & $154 \pm 14$ & $145 \pm 27$ & $140 \pm 23$ \\
\hline $\mathrm{Zn}$ & $408 \pm 15$ & $396 \pm 22$ & - & $390 \pm 31$ \\
\hline
\end{tabular}

Table 5. Results achieved for the fish tissue material with uncertainty values.

\begin{tabular}{|c|c|c|c|}
\hline \multirow{2}{*}{ Element } & $\begin{array}{c}\text { Certification results } \\
\text { from ERM-BB422 } \\
\text { Report }\end{array}$ & ET-AAS & HMDE \\
\cline { 2 - 4 } & \multicolumn{3}{|c|}{$\left[{\left.\mathrm{mg} \cdot \mathrm{kg}^{-1}\right]}\right.$} \\
\hline $\mathrm{Cu}$ & $1.67 \pm 0.16$ & - & $1.53 \pm 0.21$ \\
\hline $\mathrm{Fe}$ & $9.4 \pm 1.4$ & $8.2 \pm 2.0$ & - \\
\hline $\mathrm{Mn}$ & $0.368 \pm 0.028$ & $0.457 \pm 0.113$ & - \\
\hline $\mathrm{Zn}$ & $16.0 \pm 1.1$ & - & $14.3 \pm 2.5$ \\
\hline
\end{tabular}

The optimal mass for mineralisation of bottom sediment samples was $400 \mathrm{mg}$ and $450 \mathrm{mg}$ for tissue samples. Each round of samples was comprised of six mineralisation samples and two blank samples. For the accuracy measurements we used a certified reference material like Buffalo River sediment (RM-8704, NIST) and fish tissue (ERM-BB422, ERM). Appropriate masses of these certified materials (400 $\mathrm{mg}$ and $450 \mathrm{mg}$ ) were mineralised using adequate mineralisation procedure. The results obtained for the Buffalo River sediment material with different techniques are presented in Table 4 and for fish tissue in Table 5.

For all obtained values the expanded uncertainty $(U)$ was calculated as:

$$
U=k u_{(x i)}
$$

...where $k$ is the coverage factor, which for the probability level $95 \%$ is 2 , and $u_{(x i)}$ is standard uncertainty calculated as a standard deviation.

All certified values were in agreement with values obtained using developed methods. As can be seen in Tables 4 and 5, the accuracy and precision of proposed analytical methods is satisfactory. For RM-8704, besides Co and $\mathrm{Ni}$, other elements were determined using two techniques (with $\mathrm{Pb}$ even three). The values obtained with dif- ferent techniques can confirm that determined values are close to the real ones. This could be very useful when applying this procedure for the determination of bottom sediments samples - candidates for certified reference materials.

In ERM-BB422 only four elements from those under consideration were presented. There is a lack of certified reference materials for the fish tissue in the market, which is the next reason for production of such materials. Elements in this CRM were at very low levels, which is why only ET-AAS and DPV-MDE techniques could be applied for verification of developed procedures. However, the values achieved were in agreement with those from CRM. The uncertainty values were higher because of lower concentrations (near the LOQ levels).

The results achieved for the bottom sediment samples (from the Vistula River) are candidates for certified reference materials as presented in Table 6 .

The results achieved for the cod, cormorant, and herring tissue samples are candidates for certified reference materials as presented in Table 7.

Calibration curves for elements determined using F-AAS and ET-AAS were determined using linear regression:

Table 6. Results achieved for bottom sediment samples with uncertainty values $(n=6)$.

\begin{tabular}{|c|c|c|c|}
\hline \multirow{2}{*}{ Element } & F-AAS & ET-AAS & HMDE \\
\cline { 2 - 4 } & \multicolumn{3}{|c|}{$\left[\mathrm{mg} \cdot \mathrm{kg}^{-1}\right]$} \\
\hline & \multicolumn{3}{|c|}{ (uncertainty \%) } \\
\hline $\mathrm{Cd}$ & - & $1.91(15)$ & $1.82(13)$ \\
\hline $\mathrm{Co}$ & - & $7.74(5)$ & - \\
\hline $\mathrm{Cu}$ & $38.2(5)$ & - & $39.1(6)$ \\
\hline $\mathrm{Fe}$ & $25721(9)$ & $24973(10)$ & - \\
\hline $\mathrm{Mn}$ & $1014(7)$ & $981(8)$ & - \\
\hline $\mathrm{Pb}$ & $38.1(12)$ & $36.9(9)$ & $40.4(8)$ \\
\hline $\mathrm{Zn}$ & $318(8)$ & - & $304(7)$ \\
\hline
\end{tabular}


Table 7. Results ( $\left.\mathrm{mg} \cdot \mathrm{kg}^{-1}\right)$ achieved for tissue samples with uncertainty (\%) values $(\mathrm{n}=6)$.

\begin{tabular}{|c|c|c|c|c|c|c|}
\hline \multirow{4}{*}{ Sample } & Method & $\mathrm{Cu}$ & $\mathrm{Fe}$ & $\mathrm{Mn}$ & $\mathrm{Pb}$ & $\mathrm{Zn}$ \\
\hline \multirow{5}{*}{ Cormorant tissue } & ET-AAS & - & $11.3(12)$ & $0.87(9)$ & - & - \\
\cline { 2 - 7 } & HMDE & $1.25(10)$ & - & - & $0.17(17)$ & - \\
\cline { 2 - 7 } & F-AAS & $17.6(8)$ & $299(5)$ & - & - & $65.8(6)$ \\
\cline { 2 - 7 } & HM-AAS & - & $282(7)$ & $2.32(8)$ & $2.87(13)$ & - \\
\hline \multirow{3}{*}{ Herring tissue } & F-AAS & $17.0(6)$ & - & - & $2.62(7)$ & $62.3(5)$ \\
\cline { 2 - 7 } & ET-AAS & - & $180(8)$ & - & - & $107(5)$ \\
\cline { 2 - 7 } & HMDE & $3.2(8)$ & - & $5.31(7)$ & - & - \\
\hline
\end{tabular}

Table 8. LOD and LOQ values determined with different techniques.

\begin{tabular}{|c|c|c|c|c|c|c|}
\hline \multirow{3}{*}{ Element } & \multicolumn{3}{|c|}{ LOD } & \multicolumn{3}{|c|}{ LOQ } \\
\hline & \multicolumn{6}{|c|}{$\left[\mathrm{mg} \cdot \mathrm{kg}^{-1}\right]$} \\
\hline & F-AAS & ET-AAS & HMDE & F-AAS & ET-AAS & HMDE \\
\hline $\mathrm{Cd}$ & - & 0.12 & 0.017 & - & 0.36 & 0.051 \\
\hline Co & - & 0.28 & - & - & 0.84 & - \\
\hline $\mathrm{Cu}$ & 2.2 & - & 0.021 & 6.5 & - & 0.063 \\
\hline $\mathrm{Fe}$ & 12 & 1.3 & - & 36 & 3.9 & - \\
\hline $\mathrm{Mn}$ & 2.9 & 0.10 & - & 8.8 & 0.31 & - \\
\hline $\mathrm{Ni}$ & 12 & - & - & 35 & - & - \\
\hline $\mathrm{Pb}$ & 8.1 & 0.35 & 0.014 & 24 & 1.1 & 0.042 \\
\hline $\mathrm{Zn}$ & 10 & - & 0.019 & 30 & - & 0.057 \\
\hline
\end{tabular}

$$
y=a x+b
$$

...where $y$ is the peak area, $a$ is the slope, $x$ is the respective concentration, and $b$ is the intercept.

For determining elements with DPV-HMDE, the standard addition method was used. The limit of detection (LOD) and limit of quantification (LOQ) were determined using the parameters of standard curves. The LOD values were determined as:

$$
\mathrm{LOD}=3.3 s / a
$$

...where $s$ is the standard deviation of intercept $\left(S_{b}\right)$ and $a$ is the slope.

The LOQ values were calculated as:

$$
\mathrm{LOQ}=3 \mathrm{LOD}
$$

The LOD and LOQ values were determined for different techniques (Table 8). Linearity levels are presented in Table 9.

For homogeneity within and between bottles, additional measurements were made. From six bottles six samples were taken for mineralisation and the results for each ele- ment were calculated using analysis of variance. In each case the result was the same and variances did not differ in a statistically significant way. Therefore, the bottom sediment samples are homogenous for the $400 \mathrm{mg}$ mass and the tissue samples are homogenous for the $450 \mathrm{mg}$ mass and

Table 9. Linearity levels for selected elements with different techniques.

\begin{tabular}{|c|c|c|c|}
\hline \multirow{2}{*}{ Element } & F-AAS & ET-AAS & HMDE \\
\cline { 2 - 4 } & \multicolumn{3}{|c|}{$\left[\mathrm{mg} \cdot \mathrm{kg}^{-1}\right]$} \\
\hline $\mathrm{Cd}$ & - & $0.4-10$ & $0.06-1.0$ \\
\hline $\mathrm{Co}$ & - & $0.9-25$ & - \\
\hline $\mathrm{Cu}$ & $6.5-100$ & - & $0.07-1.0$ \\
\hline $\mathrm{Fe}$ & $40-500$ & $3.9-50$ & - \\
\hline $\mathrm{Mn}$ & $9-100$ & $0.35-10$ & - \\
\hline $\mathrm{Ni}$ & $35-500$ & - & - \\
\hline $\mathrm{Pb}$ & $25-300$ & $1.1-50$ & $0.05-1.0$ \\
\hline $\mathrm{Zn}$ & $30-300$ & - & $0.06-1.0$ \\
\hline
\end{tabular}


can be considered in subsequent operations as candidates for certified reference materials.

The proposal presented in this article for the use of three different techniques for the determination of the selected elements enables customers to select the appropriate technique to determine elements in candidates for certified reference materials, and not only the most commonly used ICP technique. In addition, verification of the results using three analytical techniques is useful for determining the reliability of the results of analyses.

\section{Conclusions}

New candidates for certified reference materials (for elements) have been proposed. These materials were prepared from bottom sediment from the Vistula River (Torun) and cod, cormorant, and herring tissues.

A sample mineralisation programme was optimised and applied to $400 \mathrm{mg}$ samples to achieve total decomposition. Without decomposition of silicates, adsorption of some elements can occur, which leads to even more than $10 \%$ lower values.

Three analytical techniques were successfully introduced for the determination of several elements. Beside Co and $\mathrm{Ni}$, every element can be determined by at least two techniques for bottom sediment samples, which confirms that values achieved are close to the real values.

For accuracy testing certified reference materials RM-8704 from NIST and ERM-BB422 from ERM were used. Values obtained for this material by applying analytical procedures showed that good accuracy was achieved and those methods could be applied for new bottom sediment and tissue samples.

Produced materials can be considered as homogeneous within and between bottles, as no statistically significant differences from variances were observed. Further studies on the metal content of the aforementioned samples have been carried out by other members of the consortium with the use of other techniques for interlaboratory comparison.

\section{Acknowledgements}

This project is financed in the framework of a grant titled "Production and attestation of new types of reference materials crucial for achieving European accreditation for Polish industrial laboratories" by the National Center for Research and Development.

\section{References}

1. MASLOV A.V., SHEVCHENKO V. P., PODKOVYROV V. N. RONKIN YU. L., LEPIKHINA O. P., NOVIGATSKY A. N., FILIPPOV A. S., SHEVCHENKO N.V. Specific Features of the Distribution of Trace and Rare Earth Elements in Recent Bottom Sediments in the Lower Course of the Severnaya Dvina River and White Sea. Lithol. Mineral Res. 49, (6), 433, 2014.
2. KRASNODĘBSKA-OSTREGA B., KACZOROWSKA M., GOLIMOWSKI J. Ultrasound-Assisted Extraction for the Evaluation of Element Mobility in Bottom Sediment Collected at Mining and Smelting Pb-Zn Ores Area in Poland. Microchim. Acta 154, 39, 2006.

3. SAVONINA E. YU., FEDOTOV P. S., WENNRICH R. Five-Step Dynamic Fractionation of Copper, Zinc, and Lead Species in Soils, Silts, and Bottom Sediments Using Rotating Coiled Columns. J. Anal. Chem. 61, (7), 702, 2006.

4. FRANKOWSKI M., ZIOŁA-FRANKOWSKA A., KOWALSKI A., SIEPAK J. Fractionation of heavy metals in bottom sediments using Tessier procedure. Environ Earth Sci. 60, 1165, 2010.

5. KHARITONOVA G. V., SIROTSKII S. E., CHIZHIKOVA N. P., KONOVALOVA N. S., MANUCHAROV A. S., TYUGAI Z., UTKINA E. V. Microelements in Fractions of Bottom Sediments of the Amur River. Lithol. Mineral Res. 49, (3), 201, 2014.

6. ZHAOKAI X., DHONDIL L., JINYONG C., SHOUYE Y., HOISOO J. Rare earth elements in bottom sediments of major rivers around the Yellow Sea: implications for sediment provenance. Geo-Mar. Lett. 29, 291, 2009.

7. PALIULIS D. Assessment of Lake Bottom Sediment Pollution by Lead and Cadmium. Pol. J. Environ. Stud. 23, (4), 1273, 2014.

8. HALLI M., SARI E., KURT M. A. Assessment of Arsenic and Heavy Metal Pollution in Surface Sediments of the Ergene River, Turkey. Pol. J. Environ. Stud. 23, (5), 1581, 2014.

9. POLYAKOV D. M., ZARUBINA N. V. Accumulation of Alkaline and Alkaline_Earth Elements in Subcolloidal Fraction of Bottom Sediment at the River-Sea Geochemical Barrier. Water Res. 41, (6), 666, 2014.

10. SHYNU R., PURNACHANDRA RAO V., KESSARKAR P. M., RAO T. G. Rare earth elements in suspended and bottom sediments of the Mandovi estuary, central west coast of India: Influence of mining. Estuar. Coast. Shelf S. 94, 355, 2011.

11. DABIOCH M., KITA A., ZERZUCHA P., PYTLAKOWSKA K. Assessment of elemental contamination in the bottom sediments from a dam reservoir using a sequential extraction technique and chemometric analysis. Cent. Eur. J. Chem. 11, (12), 1981, 2013.

12. MOREIRA S., VIVES A. E. S., NASCIMENTO FILHO V. F., ZUCCHI O. L. A. D., BRIENZA S. M. B. Evaluation of element availability in bottom sediments by synchrotron total reflection X-ray fluorescence analysis (SR-TXRF). J. Radioanal. Nucl. Ch. 270, (1), 87, 2006.

13. OVSYANY E. I., KOTELYANETS E. A., OREKHOVA N. A. Arsenic and heavy metals in the bottom sediments of the Balaklava Bay (Black Sea). Physic. Oceanogr. 19, (4), 254, 2009.

14. BOGUSH A. A., LAZAREVA E. V. Behavior of heavy metals in sulfide mine tailings and bottom sediment (Salair, Kemerovo region, Russia). Environ. Earth Sci. 64, 1293, 2011.

15. GOLDBERG E. L., GORBARENKO S. A., SHAPORENKO A. D., PHEDORIN M. A., ARTEMOVA A. V., BOSIN A. A., ZOLOTAREV K. V. SRXFA for element compositions of bottom sediments from the Okhotsk Sea. Nucl. Instrum. Meth. A. 543, 280, 2005.

16. BALJINNYAM N., FRONTASYEVA M. V., ALEKSIAYENAK YU. V. INAA for Determination of Trace Elements in Bottom Sediments of the Selenga River Basin in Mongolia. Phys. Part. Nuclei Lett. 11, (2), 199, 2014. 
17. EMELYANOV E. M., KONOVALOVA T. G. Some Results of Bottom Sediment Monitoring in Oil Production Area in the Southeastern Baltic Sea. Water Res. 40, (7), 733, 2013.

18. KABAŁA C., BOJKO O. Trends in Trace Element Concentrations in Holocene Bottom Sediments of a Lake Wielki Staw in the Karkonosze Mountains. Pol. J. Environ. Stud. 23, (2), 357, 2014.

19. STANISZEWSKI R. Heavy Metals in Waters and Sediments of Rivers Affected by Brown Coal Mine Waters. Pol. J. Environ. Stud. 23, (6), 2217, 2014.

20. KRASNODĘBSKA-OSTRĘGA B., STRYJEWSKA E., GOLIMOWSKI J. Voltammetric determination of thalium and lead in sediment samples. Chem. Anal. 50, 807, 2005.

21. KRASNODEZBSKA-OSTREGA B., DMOWSKI K., STRYJEWSKA E., GOLIMOWSKI J. Determination of thalium and other elements ( $\mathrm{As}, \mathrm{Cd}, \mathrm{Cu}, \mathrm{Mn}, \mathrm{Pb}, \mathrm{Se}, \mathrm{Sb}$ and $\mathrm{Zn}$ ) in water and sediment samples from the vicinity of the Zinc-Lead Smelter in Poland. J. Soils Sed. 5, 71, 2005.

22. POLAK-JUSZCZAK L. Trace elements in the livers of cod (Gadus morhua L.) from the Baltic Sea: levels and temporal trends. Environ. Monit. Assess. 185, 687, 2013.

23. POLAK-JUSZCZAK L. Temporal trends in the bioaccumulation of trace metals in herring, sprat, and cod from the southern Baltic Sea in the 1994-2003 period. Chemosphere 76, 1334, 2009.

24. IKEM A., EGIEBOR N. O. Assessment of trace elements in canned fishes (mackerel, tuna, salmon, sardines and herrings) marketed in Georgia and Alabama (United States of America). J. Food Compos. Anal. 18, 771, 2005.

25. SKORIC S., VISNJIC-JEFTIC Z., JARIC I., DJIKANOVIC V., MICKOVIC B., NIKCEVIC M., LENHARDT M. Accumulation of 20 elements in great cormorant (Phalacrocorax carbo) and its main prey, common carp (Cyprinus carpio) and Prussian carp (Carassius gibelio). Ecotox. Environ. Safe. 80, 244, 2012.

26. NAM D., ANAN Y., IKEMOTO T., OKABE Y., KIM E., SUBRAMANIAN A., SAEKI K., TANABE S. Specific accumulation of 20 trace elements in great cormorants (Phalacrocorax carbo) from Japan. Environ. Pollut. 134, 503, 2005

27. ERSOY B., CELIK M. The essential and toxic elements in tissues of six commercial demersal fish from Eastern Mediterranean Sea. Food Chem. Toxicol. 48, 1377, 2010.
28. STORELLI M. M., CUTTONE G., MARCOTRIGIANO G. O. Distribution of trace elements in the tissues of smooth hound Mustelus mustelus (Linnaeus, 1758) from the southern-eastern waters of Mediterranean Sea (Italy). Environ. Monit. Assess. 174, 271, 2011.

29. SUBOTIC S., VISNJIC-JEFTIC Z., SPASIC S., HEGEDIS A., KRPO-CETKOVIC J., LENHARDT M. Distribution and accumulation of elements ( $\mathrm{As}, \mathrm{Cu}, \mathrm{Fe}, \mathrm{Hg}, \mathrm{Mn}$, and $\mathrm{Zn}$ ) in tissues of fish species from different trophic levels in the Danube River at the confluence with the Sava River (Serbia). Environ. Sci. Pollut. Res. 20, 5309, 2013.

30. ALHASHEMI A. H., KARBASSI A., KIABI B. H., MONAVARI S. M., SEKHAVATJOU M. S. Bioaccumulation of trace elements in different tissues of three commonly available fish species regarding their gender, gonadosomatic index, and condition factor in a wetland ecosystem. Environ. Monit. Assess. 184, 1865, 2012.

31. SCHENONE N. F., AVIGLIANO E., GOESSLER W., CIRELLI A. F. Toxic metals, trace and major elements determined by ICPMS in tissues of Parapimelodus valenciennis and Prochilodus lineatus from Chascomus Lake, Argentina. Microchem. J. 112, 127, 2014.

32. MAYFIELD D. B., FAIRBROTHER A. Examination of rare earth element concentration patterns in freshwater fish tissues. Chemosphere 120, 68, 2015.

33. RUELAS-INZUNZA J., SOTO-JIMENEZ M. F., RUIZFERNANDEZ A. C., BOJORQUEZ-LEYVA H., PEREZBERNAL H., PAEZ-OSUNA F. ${ }^{210} \mathrm{Po}$ Activity and Concentrations of Selected Trace Elements (As, Cd, Cu, Hg, $\mathrm{Pb}, \mathrm{Zn}$ ) in the Muscle Tissue of Tunas Thunnus albacares and Katsuwonus pelamis from the Eastern Pacific Ocean. Biol. Trace Elem. Res. 149, 371, 2012.

34. FERNANDEZ W. S., DIAS J. F., BOUFLEUR L. A., AMARAL L., YONEAMA M. L., DIAS J. F. Bioacumulation of trace elements in hepatic and renal tissues of the white mullet Mugil curema Valenciennes, 1836 (Actinopterygii, Mugilidae) in two coastal systems in southeastern Brazil. Nucl. Instrum. Meth. B. 318, 94, 2014.

35. SHOHAM-FRIDER E., KEREM D., RODITI-ELASAR M., GOFFMAN O., MORICK D., YOFFE O., KRESS N. Trace elements in tissues of cetacean species rarely stranded along the Israeli Mediterranean coast. Mar. Pollut. Bull. 83, 376, 2014.

36. MENDIL D., TUZEN M. Assessment of trace elements in animal tissues from Turkey. Environ. Monit. Assess. 182, 423, 2011. 
